\title{
The Marxist Theory of the State: An Introductory Guide
}

\author{
Ugumanin Bassey Obo \\ Department of Political Science \\ University of Calabar, Calabar, Nigeria \\ Maurice Ayodele Coker \\ Department of Political Science \\ Benue State University, Makurdi, Benue State, Nigeria \\ mauricecoker@unical.edu.ng
}

\section{Doi:10.5901/mjss.2014.v5n4p527}

\begin{abstract}
This essay seeks to familiarise young students of society with the basic propositions of the Marxist theory of the state. It discusses the concept and characteristics of the state, and also examines the central tenets and elements of the Marxist perspective on the origin and nature of the state. The criticisms often levelled against the Marxist view of the state, as well as the Marxist rebuttal of the critique are also highlighted. Moreover, the core principles of the liberal theories of the state - to which the Marxist theory is opposed - are outlined so as to situate the issues of discourse in proper contexts.
\end{abstract}

Keywords: State; marxism; theory; class struggle; productive force; means of production

\section{Introduction}

No theory of the state is ever intelligible save in the context of its time. What men think about the state is the outcome always of the experience in which they are immersed.... Harold J. Laski (1967: 1)

As an intellectual perspective and a body of knowledge, Marxism has continuously suffered "critical pulverizations and attacks" (Yaqub, 2000: 86) from many quarters, and most of these have been due to misunderstanding or outright mischief and dishonesty. Marxism's contributions toward mankind's search for solutions to society's problems have been enormous; in fact, it can be said that the arrival of Marx and Engels on the intellectual podium signalled a revolution in man's attempts to acquire knowledge for the understanding of the human society.

This essay focuses attention on one of the issues of discourse in Marxist thought - namely, the State. An attempt shall be made to acquaint young students of society with Marxism's theoretical position on the state. This paper is intended to serve as an introductory guide for beginners in the study of Marxist thought, with specific attention on the theory of the State. This is imperative in view of the difficulties that young students encounter in trying to understand some of the ideas and writings in the Marxist tradition. As Ansa (1994: 235) has observed,

Marxism as a social thought deals with all areas of man's economic and social life. Its basic principles can only be internalised after years of stubborn, repeated and intensive reading. Reading only secondary literature, especially by anti-Marxists does not help much. Any student who wants to have deep insights into Marxism must read, among others, the original works of Marx, Engels, Lenin and Mao Tse-Tung (emphasis added).

The desire to assist the upcoming students of society to cope with the daunting challenges of understanding Marxist thought is the main motivation for this essay. The inspiration for this paper is also partly derived from an exciting essay written by Oladipo (1991). Although it was published many years ago, that essay still remains an interesting introductory piece. However, this paper contains only a fraction of what the beginner needs to know about the Marxist theory of the State. To argue otherwise would amount to being unnecessarily presumptuous. This paper is organised into five parts; part one contains the introductory comments; in part two, the meaning and salient elements of the state are highlighted. In part three, we examine some of the contending theories of the state, and in the fourth part, the basic assumptions of, and some of the criticisms against, the Marxist theory of the State are presented. Part five contains the conclusion. 


\section{The State: Meaning and Characteristics}

There is no definition of the state that is universally accepted and this is not peculiar to the concept of the State; it is a fundamental and an unresolved issue in the study of human society. According to Rodee, Anderson, Christol, and Greene (1983: 20), a measure of the difficulty of answering such questions as what the state is, how it begins and develops, and what it does, is the reluctance of many of those who offer opinions about the nature of the state to define precisely what the state is. As they put it, "no one definition will please everybody, and many definitions may please only those who write them."

Also commenting on the concept of the State, Hartmann (1994: 219) points out that as a legal concept, the State delineates a territory within which given State institutions/apparatuses have jurisdiction, for example, the monopoly of the use of legitimate violence. One may also take the state to be an organisation within the society where it co-exists and interacts with other formal and informal organisations from families to economic enterprises or religious organisations. It is however distinguished from the myriad of other organisations in seeking predominance over them and in aiming to institute binding rules regarding the other organisations' activities (Bratton, 1989, cited in Hartman, 1994: 219).

The state has also been conceptualised as the most inclusive organisation which has formal institutions for regulating the most significant external relationships of the men within its scope. It is the basic political unit, a grouping of individuals who are organised in a defined territory for the pursuit of secular common welfare, the maintenance of law and order and the carrying out of external relations with other groups similarly organised (Anifowose, 1999: 85). The point has also been made that a state is the organisation of which government is the administrative organ, and that it has a constitution, a code of laws, a way of setting up its government, and a body of citizens. Moreover, it is opined that the state is a form of human association which, acting through laws as promulgated by a government, endowed to this end with coercive power, maintains within a community territorially demarcated, the universal external conditions of social order (Maclver, 1966, cited in Anifowose, 1999: 86).

According to Hoffman and Graham (2009: 13), the question of what the State is, is linked to the question of when the state emerged historically. Quoting Dunleavy and O'Leary (1987), they point out that the State, in one account, is defined in terms of five attributes, namely: a public institution separated from the private activities of society; the existence of sovereignty in unitary form; the application of laws to all who live in a particular society; the recruitment of personnel according to bureaucratic as opposed to patrimonial criteria; and the capacity to extract revenue (tax) from a subject population. Hoffman and Graham (2009: 32 - 33) also point out that the state can be defined in a way that sees its central attribute as the exercise of legitimate force; is based upon morality, or a mixture of the two. In their words, when it is defined in a way that stresses the importance of force, then it can be argued that modern states are crucially different from pre-modern states, but like all States, they claim to exercise a monopoly of legitimate force.

From a purely liberal point of view, Weber (1949) regards the state as a human community that (successfully) claims the monopoly of the legitimate use of physical force within a given territory. The State is also considered as the sole source of the "right" to use violence. For him, the State is a concrete administrative structure or organisation which has the physical force that it uses to enforce obedience. This state contains several specialised structures which are clearly defined, complex, formal and permanent (Sha, 1999: 3). According to Chinoy (1967), as a concept in social science, the State refers to those institutions that establish who shall possess the monopoly of the legitimate use of physical force within a given territory, and that define how the power which rests upon that monopoly shall be organised and used. The person who exercises this power composes the government (cited in Oyediran, 1998: 17). On his part, Laski (1961) points out that the state is a territorial society divided into government and subjects claiming within its allotted physical area, a supremacy over all institutions. He also emphasises that the state,

is in fact the final legal depository of social will. It sets the perspective of all other organisations. It brings within its power all forms of human activities, the control of which it deems desirable. It is moreover, the implied logic of this supremacy that whatever remains free of its control does so by its permission (cited in Oyediran, 1998: 17)

In his analysis, Heywood (2007: 90) points out that the term "State" has been used to refer to a bewildering rage of things: a collection of institutions, a territorial unit, a philosophical idea, an instrument of coercion or oppression, and so on. The confusion, according to him, stems, in part, from the fact that the State has been understood in three different ways, from an idealist, functionalist and organisational perspectives. The Idealist approach to the State is most clearly reflected in the writings of Hegel, who identified three "moments" of social existence: the family, civil society, and the state, and conceived of the State as an ethical community underpinned by mutual sympathy - "universal altruism". Functionalist approaches to the State focus on the role or purpose of State institutions. The central function of the State is invariably seen as the maintenance of social order, the State being defined as that set of institutions that uphold order 
and deliver social stability. On its part, the organisational view regards the State as the apparatus of government in its broadest sense: that is, as that set of institutions that are recognisably "public" in that they are responsible for the collective organisation of social existence and are funded at the public's expense (Heywood, 2007: 90).

It is important to note that the State is a special and unique form of human association; but it differs from other associations on the following grounds:

(a) It alone has the right to exercise force to compel obedience to its orders. It may impose any penalty, including imprisonment, deportation or death, as it chooses on its citizens;

(b) It is an all-inclusive association, i.e., all departments of life are, at least potentially, under its control while no other association caters for more than a limited department of life. All other organisations and activities within the national frontiers are subordinate to the State;

(c) It is compulsory for everybody, and not voluntary, like other associations. Everybody must belong to a State;

(d) The basis of the State is territorial, that is, its jurisdiction includes everybody who was born in a certain stretch of territory and continues to reside there;

(e) It has permanence. Other associations are not permanent; they may arise, disappear, and re-emerge, unite and separate with ease; and

(f) It has complete independence and sovereignty. The State is the ultimate source of legal competence, and in principle, it has the power to make and enforce laws with all the means of coercion it cares to employ, and it is also free from foreign control (Anifowose, 1999: 86-87).

From the foregoing analysis, four key characteristics or essential elements of the State can be identified. The first two can be taken to be its "physical" elements, and the last two can be regarded as its "spiritual" or "metaphysical" elements (Johari, 2005: 56). These are:

a) Population: Since the State is a human association, the first element that constitutes it is the people (Johari, 2005: 56). The State is composed of men, women and children. The population of the state can thus be defined as including citizens or subjects who enjoy full civil rights and owe allegiance, nationals or natives of the dependencies of a State, slaves, aliens or citizens and subjects of other States who reside within the territory of a given state (Anifowose, 1999:88).

b) Territory: Every State is situated within a defined territory with clearly recognisable boundaries that do not overlap the area of any other State. A State's territory includes not merely the land itself, but also the air above the land, the waters extending outward from its coast for a distance of twelve miles, the lakes and mountains and all other topographical features as well as natural resources (Anifowose, 1999:87-88). It is important to note that States are of different sizes.

c) Government: This is the instrument through which the overall will of the State is articulated and expressed. Indeed, government is the soul of the State (Johari, 2005: 58), and in the words of Harold Laski (1961), every State, in short, is a territorial society divided into government and subjects, the government being a body of persons within the territorial society, who are entitled to use coercion to see that these imperatives are obeyed (cited in Paki and Inokoba, 2006:99). The group of people who superintends over or oversees the affairs of the State at any given time constitutes the government of that State.

d) Sovereignty: According to Crick (1973), the modern state is, above all also a sovereign state: it seeks to be the sole authority and the only effective power within a given territory, and seeks to preserve the independence of that territory (cited in Oyediran, 1998: 21). Sovereignty is the highest power of the State that distinguishes it from all other associations of human beings. It has two aspects - internal and external. It means that inside the State there can be no other authority that may claim equality with it. In the external sphere, it implies that the country should be free from foreign control of any kind - although the State can voluntarily accept the memberships of international organisations (Johari, 2005: 59).

\section{A Note on Some Contending Theories of the State}

Apart from Marxism, a number of other perspectives shave been developed to explain the genesis and nature of the State. The emergence of these varying perspectives underscores the lack of consensus among philosophers and scholars on the origin and character of the State. Due to the encumbrances of time and space, we shall only briefly comment on some of the non-Marxist theories of the State. A brief examination of some of these theories has been presented by Oyediran (1998: 19) as follows:

(a) The Divine Theory - This attributes the origin of State to divine creation, and the State is seen as an institution 
ordained by God, and their rulers were regarded as God's own emissaries on earth. This theory had its root in the ancient oriental empires, Hebrew and Christian teachings and protestant reformation;

(b) The Social Contract Theory - The theory of popular sovereignty constitutes the basis of this theory, which contended with, and displaced the divine theory. The theory of popular sovereignty postulates that the State is the creation of men through a social contract to which they had all consented. Hobbes, Locke and Rousseau were the foremost exponents of this theory;

(c) The Force Theory - This holds that the State is a creation of conquest and coercion of the weak by the strong. The State was seen as evil because it was a way of oppressing the poor; and

(d) The Natural Theory - This is derived from Aristotle's position that man is a "political animal" whose selfactualisation can only be attained in a state. Man and the State were seen as mutually inclusive and inseparable and that the State is not an artificial creation.

It is instructive to note that the Marxist theory of the State emerged mainly as a reaction to the liberal theories or the "liberal-democratic (or capitalist) view of the State" (Oladipo, 1991: 162). Thus, at this point, a brief comment on the liberal view of the State would be appropriate. In the liberal theory (especially the "social contract" variant), the State is said to have arisen out of a voluntary agreement made by individuals who recognised that only the establishment of a sovereign power could safeguard them from the insecurity, disorder and brutality of the "state of nature". It is argued that without a State, individuals abuse, exploit and enslave one another, and with a State, order and civilised existence are guaranteed and liberty is protected. This theory thus regards the State as a neutral arbiter amongst the competing groups and individuals in society, as well as an umpire that is capable of protecting each citizen from the encroachments of fellow citizens. The neutrality of the State reflects the fact that the State acts in the interest of all citizens, and therefore represents the common good or public interest (Heywood, 2007: 93).

In his analysis, Oladipo (1991: 163) points out that liberal-democratic theorists regard the State as a necessary force in human society whose power over the individual should be as minimal as possible. He stated that these theorists venerate individual interests and personal freedom to such an extent that they see the role of the State purely in terms of the protection of individual rights and liberties. Moreover, he posits that for the liberal theorists, political society (the State) is a "human contrivance for the protection of the individual's property in his person and goods and (therefore) for the maintenance of orderly relations of exchange between individuals who are regarded as proprietors themselves".

As a critique, it is easy to see that the above theory poses more questions than it answers. First, it implies that the origin of the State is part of the natural order of things, as the need for protection and escape from Hobbes' barbarism has always existed in all human societies. This means that the State has always existed from antiquity and it will exist in perpetuity. But this is false. Second, the theory is significantly silent on who it was that proposed the social contract: a contract is usually between identifiable parties - so who represented the proposed state? Who were those recruited to run the state? Third, due to the theory's neutralist assumption about the state, it is believed that because the state arose from the collective will of society, it is a benevolent institution serving the interests of the whole of society. From the repression of sections of society by all states, which often degenerates into open fascism, this assumption of the neutral state is clearly bogus (Onimode, 1985: 202-203).

\section{Marxist Theory of the State: Basic Assumptions and Objections}

Marxists clearly reject the major propositions of the liberal theories about the State. They believe that irrespective of how "liberal" or "democratic" a state claims to be, it is mainly an instrument for the domination, oppression and exploitation of the economically weak class (i.e., the class of the poor and non-owners of the means of production) by the powerful and dominant class (i.e., the class of the rich and owners of means of production). Briefly put, the state is principally a tool for the establishment and maintenance of the hegemony of the rich and the powerful over the poor. Indeed, "in an antagonistic class society the State is a political instrument, a machine for maintaining the rule of one class over another" (Lenin, n.d., cited in Johari, 2005: 72).

It should be stated that it is more fruitful for the Marxist theory of the State to be contextualised within the framework of the "material interpretation of history", a historical approach which interconnects the substructure of society - i.e., the mode of production and its corresponding production relations - and the superstructure of society, namely, the whole network of social, political, legal, moral, cultural and intellectual life of society. Indeed, Marxists have argued that the State cannot be understood separately from the economic structure of society, and that the State emerges out of, and in a sense reflects the class system (Oladipo, 1991: 165; Heywood, 2007: 94).

Marxists believe that three major attributes of the State can be identified. These are: 
(a) It is a public power in contrast to the direct organisation of the armed people which existed in tribal society. A feature of the State is not its power of coercion in general which is to be found in some form in any society, but above all its public power, that is a power that does not coincide with the mass of population and is exercised by a special category of people;

(b) The state organisation of society presupposes the levying of taxes that are needed for the upkeep of the apparatus of power. As internal and external contradictions become more intense and the State apparatus grows, its maintenance swallows up more and more of the resources of society; and

(c) The subjects of the state are divided not according to blood relationship but on the basis of territory. The power of the state is exercised directly over a certain territory and its population, and this territorial division of people effects the development of economic ties and the creation of political conditions for their regulation (Johari, 2005: 72-73).

As earlier stated, for the Marxists, the state is primarily an apparatus used by the class of wealthy people for the suppression and domination of the "have-nots", and it came into being only at a particular stage in the historical development of human society. An interesting element of this view of the State can be gleaned from the proposition that the State as a political power is not inevitable; there were periods in the development of society when it did not exist, and as society develops, there would be a time when it would cease to exist. In the early periods of development of society when the mode of production was very rudimentary and production relations were largely undifferentiated, there was clearly no need for the state. This implies that the state is not natural to all human societies - there have been societies without states, and this underscores the fact that before the emergence of private property in human history from the slave mode of production, there was no state (Oladipo, 1991: 165; Onimode, 1985: 203). This view has been reinforced by Johari (2005: 72) simply in the following words:

Marxism tells us that the mode of production of the material means of life determines in general the social, political and intellectual processes of life. In the social production of the means of life, men enter into definite and necessary production relations which correspond to a definite stage in the development of their productive forces. There was no State in the primitive communistic system as there were no contending classes

But ....the invention of the new means of production like cultivation of land and smelting metals caused significant social changes. Social divisions grew that led to the disappearance of the primitive pattern of communistic life; private property system arose and that opened the way of exploitation of the 'have-nots' by the 'haves'...

Another important element of the Marxist theory of the State is the idea of the "withering away of the State". According to Oladipo (1991: 169), the idea that the state will wither away at a certain stage of the development of society is based on the Marxist understanding of the origin and nature of the State; and since the state is a product of the division of society into antagonistic classes and because it exists for keeping the conflict between these classes in order, it will wither away when these classes cease to exist and we have a classless society.

Engels (1969) had long argued that the proletariat would size state power and turn the means of production into state property, and that as soon as there is no longer any social class to be held in subjection, and class rule and the individual struggle for existence are removed, nothing more remains to be held in subjection - nothing necessitating a special coercive force, a State. According to him, the bourgeois State does not "wither away", but is "abolished" by the proletariat in the course of the revolution. What withers away after this revolution is the proletarian state or semi-state (Lenin, 1984: 19 and 20).

It should be stated that although the withering away of the State is inevitable (i.e., from the Marxist perspective), it is a process that can be put in motion only when the proletariat has seized state power and organised itself as the ruling class - after the revolutionary overthrow of the bourgeoisie (Oladipo, 1991: 170). This is the product of the class struggle - in which, as a result of the contradictions between the workers and the capital-owners (i.e., the proletariat and bourgeoisie), the former would rise, confront, and eventually topple the latter. As pointed out elsewhere (Obo, 2002: 5463 ), the surplus value (wealth) of the society is produced by the workers, but it is expropriated and privatised by the exploiting class; it is the injustice and the cruelty inherent in this act that propel the working people into revolutionary upheaval against the oppressor class.

Another vital element of the Marxist understanding of the State is the notion of the "dictatorship of the proletariat." This phrase implies that at a given stage in the development of the bourgeois society, the workers would seize the institutions and structures of the state, replace the bourgeois state, and they would then constitute the ruling class. As Yaqub (2000:94) puts it,

...this would have to be brought about through the capture of state power by the proletariat - the most revolutionary class in history. This class would, with power in its hands, institute its dictatorship as a transitional phase to the eventual 
and the ultimate abolition of state, private property, class distinctions and other privileges. It is in the future communist society that equality and freedom of man could be restored, the alienation of man and the monstrous division of labour so characteristic of capitalism would all come to an end, too...

Under the dictatorship of the proletariat, the State is seen as an instrument through which the dominant class (by then the proletariat) could repress and subdue other classes. It is also regarded as a means of safeguarding the gains of the revolution by preventing counter-revolution mounted by the (then) dispossessed bourgeoisie. During this period, the state performs - among other functions - the role of instituting and promoting a new and higher mode of social production, the substitution of large-scale socialist production for capitalist production (Heywood, 2007: 95; Oladipo, 1991: 171). The State, during this era, becomes a tool for the defence and promotion of the interests of the workers in the society.

Some criticisms have been levelled against the Marxist view of the State. For instance, it has been contended that it is wrong to say that the State is a mere instrument of exploitation and oppression by one class over another since it is an agency of public welfare, and its ultimate aim is, in Aristotelian sense, to make "good life" possible for its citizens. It is also said that the factor of exploitation should not be treated as the only or decisive factor in making and sustaining the entire political structure since "many factors contributed to create the kind of political loyalty without which the state could never have grown to maturity." It has equally been argued that to treat the State as a mere apparatus of coercion is a mistake; though it is true that the State uses force to deal with its enemies and it exercises coercion to seek the enforcement of its laws, force is not the only factor that commands obedience of the people (Heywood, 2007: 74).

The foregoing critique which denies the class essence of the state has been dismissed as having missed the essential point of the Marxist theory of the state. It is opined that Marxists do not deny that the state performs other functions, apart from its primary function of the management of politics. What Marxists are saying is that whatever welfare or socio-cultural functions the state might perform do not remove the class essence of the state - so long as these functions do not abolish classes and the socio-economic arrangement that promotes the exploitation of one class by another. It is also reasoned that the state in a class society performs some welfare and socio-cultural functions not because it is autonomous, but because through the performance of these functions, it disguises its essence as a coercive instrument for the subjugation of the oppressed class(es). Even then its coercive and oppressive nature becomes obvious in moments of crisis when the basis of its power is challenged (Oladipo, 1991: 172).

Another incisive response to the critics has been presented by Onimode (1985), who posits that the claim that the state exists for the reconciliation of classes, for the alleviation of class antagonisms and the preservation of society rests on false assumptions, one of which is that the state is neutral between social classes and exists in the interest of society as a whole. But, in his words,

how can an institution established, manned and controlled by the most powerful class be indifferent to the direction and outcome of the class struggle? This is impossible. Yet, this neutrality of the state is required as a camouflage in the false consciousness of masking true class interests, which is an integral part of bourgeois ideology. State neutrality is ideologically apologetic (Onimode, 1985: 204).

Another criticism usually levelled against the Marxist view of the State has to do with the proposition that the State will wither away after classes have ceased to exist in society. The argument here is that even if it were possible to eliminate classes, the state may continue to be. For, as it has been opined, "you may get rid of class struggle in the Marxist sense, and still find that men will persist in quarrelling". This position is said to rest on the failure to make a distinction - which is very crucial - between social power and the state. There is no doubt that, "there is coercive power in every human community and there was one in the tribal system and in the family, but there was no state... the distinguishing feature of the state is the existence of a separate class of people in whose hands power is concentrated." Thus, since social power predates the appearance of the State as a public power over society, "it will continue in one form or another even after the state disappears." This social power will take care of whatever quarrels may arise in society (Oladipo, 1991: 172-173).

\section{Conclusion}

In the preceding passages, an introductory analysis of the Marxist theory of the state has been presented. The point has been highlighted that the Marxist perspective of the state is opposed to the liberal theoretical traditions which deny the class essence of the state. These non-Marxist theories regard the state as a neutral and non-partisan force established 
in the society for the purpose of maintaining law, order, and stability, as well as the promotion of the welfare of all citizens. This implies that the state is an objective organ instituted for the protection and furtherance of the interests of all citizens, irrespective of their position in the production process or relations of production.

The Marxist view of the State clearly rejects the above propositions; it sees the State as essentially an instrument of exploitation and domination of one class (the poor, workers, and non-owners of means of production) by another class (the rich and the capital-owners). Marxists argue that the state is established by the most powerful class in society; it is used by this dominant class to suppress and oppress other social classes, and in the process, it is a tool for the consolidation and reproduction of the dominant class. The State is used for these ends in class struggle through the protection of private property and the exploitation of the weaker classes, which are based ultimately on force (Onimode, 1985:203-204).

We have also tried to show that according to the Marxists, the state emerged at a given stage in the development of human society as a result of the emergence of classes whose interests are mainly irreconcilable. That is, the state did not exist prior to the emergence of classes in human society. In the light of this, Marxists believe that at a given time in the evolution of the society, classes shall cease to exist, and the state shall become a thing of the past by "withering away". This is after the proletariat must have toppled the bourgeois class and assumed the status of the ruling class by establishing the "dictatorship of the proletariat".

\section{References}

Anifowose, Remi (1999). "State, Society and Nation" in Remi Anifowose and Francis C. Enemuo eds.; Elements of Politics. Lagos: Sam Iroanusi Publications

Ansa, A. (1994). "Marxist Sociology/Anthropology" in Onigu Otite ed., Sociology: Theory and Applied. Lagos: Malthouse Press Ltd.

Bratton, Michael (1989). "Beyond the State: Civil Society and Associational Life in Africa" in World Politics, Vol. 6, No. 3, April

Chinoy, Ely (1967). An Introduction to Sociology. New York: Random House

Crick, Benard (1973). Basic Forms of Government. London: Macmillan

Dunleavy, P. and B. O'Leary (1987). Theories of the State. London and Basingstoke: Macmillan

Engels, F. (1969). Anti-Duhring. Moscow: Progress Publishers

Hartman, Jeannette (1994). "The State in Tanzania" in Ulf Himmelstrand et al eds., African Perspectives on Development. London: James Currey Ltd.

Heywood, Andrew (2007). Politics, Third edition. Basingstoke: Palgrave Macmillan.

Hoffman, John and Paul Graham (2009). Introduction to Political Theory. $2^{\text {nd }}$ edition. Edinburgh: Pearson Education Ltd.

Johari, J. C. (2005). Principles of Modern Political Science. New Delhi: Sterling Publishers Private Ltd.

Laski, Harold J. (1967). A Grammar of Politics, $5^{\text {th }}$ edition. London: George Allen and Unwin (Publishers) Ltd.

(1961). Introduction to Politics. London: George Allen and Unwin

Lenin, V. I. (1984). The State and Revolution: The Marxist Theory of the State and the Tasks of the Proletariat in the Revolution. Nigeria: Progressive and Socialist Books Depot.

(n.d.). "The State" in Collected Works, Vol. 29

Maclver, R. M. (1966). The Modern State. London: OUP

Obo, Ugumanim Bassey (2002). "The Marxist Theory of Surplus Value: A Note for Beginners" in West African Journal of Research and Development in Education, Vol. 9, No. 1, March

Oladipo, Olusegun (1991). "The Marxist Theory of the State" in F. A. Adeigbo ed., Readings in Social and Political Philosophy, Vol. I. Ibadan: Claverianum Press

Onimode, Bade (1985). An Introduction to Marxist Political Economy. London: Zed Books Limited

Oyediran, Oyeleye (1998). Introduction to Political Science. Ibadan: Oyediran Consults International.

Paki, Fidelis and Preye Inokoba (2006). An Invitation to Political Science. Port-Harcourt: Kemuela Publications

Rodee, Carlton Clymer, Totton James Anderson, Carl Quimby Christol, and Thomas H. Greene (1983). Introduction to Political Science. New York: McGraw-Hill Book Company.

Sha, Dung Pam (1999). "Theorising the Nigerian State: Pitfalls and the Search for an Alternative Framework of Analysis", Being a paper presented to the $11^{\text {th }}$ General Assembly of the Social Science Council of Nigeria held at the Women Development Centre, Abuja, July $5-7$.

Weber, M. (1949). "Politics As A Vocation" in H. H. Gerth and M. Wright eds., From Max Weber: Essays in Sociology. New York: Oxford University Press

Yaqub, Nuhu O. (2000). "Marxism and the End of History and the Last Man: A Critical Review" in Annals of the Social Science Academy of Nigeria, No. 12, January - December. 